\title{
PENANGANAN POLISI TERHADAP KASUS PERDAGANGAN PEREMPUAN DAN ANAK DI KALIMANTAN DAN JAWA
}

\author{
Anggreany Haryani Putri \\ Universitas Bhayangkara Jakarta Raya \\ anggreany.haryani@dsn.ubharajaya.ac.id \\ Koesparmono Irsan \\ Universitas Bhayangkara Jakarta Raya \\ koesparmono.irsan@dsn.ubharajaya.ac.id
}

\begin{tabular}{|c|c|c|}
\hline Naskah diterima: & Revisi: & Naskah disetujui: \\
$26 / 5 / 2019$ & $31 / 05 / 2019$ & $31 / 05 / 2019$ \\
\hline
\end{tabular}

\begin{abstract}
Abstrak
Penanganan kasus perdagangan perempuan dan anak yang dilakukan polisi di daerah Jakarta, Subang, Cirebon, Indramayu, Surabaya, Malang, Situbondo, Batam, Pontianak, Sambas, Sanggau, dan Singkawang. Modus dari perdagangan manusia pada umumnya hampir sama. Modus trafficking berkisar pada korban dibujuk, dijebak atau diiming-imingi pekerjaan ditempat seperti café, toko, atau pembantu rumah tangga dan lain-lain. Ternyata akhirnya mereka tertipu dan diperkerjakan pada tempat prostitusi atau tempat hiburan lain yang harus melayani pelanggan atau kemudian tidak mendapat bayaran. Modus lain yang mencolok adalah yang melibatkan bayi, di Batam Riau, penjualan bayi ke negara tetangga dengan cara yang sangat tidak manusiawi yaitu bayi tersebut ditempatkan di dalam kotak stereofoam dan di beri susu yang telah dicampur dengan obat penenang. Modus khas yang lain yaitu di Sambas yang disebut pengantin pesanan. Korban pada umumnya mempunyai motif / kebutuhan ekonomi yang kuat dan berpendidikan rendah sehingga mereka mudah menjadi korban. Pandangan masyarakat juga menjadi faktor pemicu adanya Trafficking, misalnya ada orang tua yang merasa tidak dirugikan karena anaknya memberikan nafkah kepada mereka. Hasil penelitian ini menunjukkan berbagai kendala yang dihadapi polisi dalam mengungkap berbagai kasus perdagangan perempuan dan anak. Seperti Hukum Adat yang terdapat didaerah tersebut menganggap kasus yang terjadi bukalah sebuah Crime tetapi merupakan adat dan kebiasaan. Selain itu banyak korban tidak melanjutkan laporannya karena mereka tidak menganggap dirinya adalah korban Human Trafficking. Serta faktor kendala yang bahwa masyarakat menganggap hal ini adalah sebuah perjanjian biasa yang dibuat sesuai dengan pasal 1320 KUHPerdata namun mereka tidak menyadarinya bahwa didalamnya terdapat unsur penipuan yang berakibat terpenuhinya unsur Human Trafficking.
\end{abstract}

Kata Kunci : Human Trafficking, Penanganan Polisi

\begin{abstract}
Handling cases of trafficking of women and children by the police in the areas of Jakarta, Subang, Cirebon, Indramayu, Surabaya, Malang, Situbondo, Batam, Pontianak, Sambas, Sanggau, and Singkawang. The mode of trafficking in general is almost the same. The trafficking mode revolves around victims being persuaded, trapped or lured by jobs in places
\end{abstract}


such as cafes, shops, or housemaids and others. It turned out that they were eventually deceived and hired in a place of prostitution or other entertainment venues that had to serve customers or later not get paid. Another striking mode is involving babies, in Batam Riau, selling babies to neighboring countries in a very inhuman way, namely the baby is placed in a stereofoam box and given milk mixed with sedatives. Another typical mode is in Sambas, which is called the bride of the order. Victims generally have strong / low-educated economic motives / needs so that they easily become victims. The view of the community is also a trigger factor for Trafficking, for example, there are parents who feel they are not harmed because their children provide income for them. The results of this study indicate various obstacles faced by the police in uncovering various cases of trafficking in women and children. As with Customary Law in the area, the case that occurred was not a Crime but was a custom and a habit. In addition, many victims did not continue their reports because they did not consider themselves victims of Human Trafficking. As well as the constraints that the community considers this is an ordinary agreement made in accordance with article 1320 of the Civil Code but they do not realize that in it there is an element of fraud which results in the fulfillment of the element of Human Trafficking.

Keywords: Human Trafficking, Police Handling

\section{PENDAHULUAN}

Sebagaimana banyak negara lainnya di dunia, Indonesia juga tengah menghadapi masalah kejahatan yang berhubungan dengan perdagangan perempuan dan anak dengan berbagai bentuk yang relatif sulit untuk diatasi. Temuan awal Pusat Kajian Wanita dan Jender Universitas Indonesia, menunjukkan ada sejumlah perempuan Indonesia maupun asing telah di tipu atau di paksa untuk membawa narkoba dari dan ke Indonesia. Tampaknya pelaku perdagangan narkoba internasional mula-mula mengencani para perempuan yang kemudian akan di manipulasi atau di paksa untuk membawa narkoba ke tempat lain. Temuan awal mengindikasikan ada berbagai jenis metode yang digunakan oleh pelaku perdagangan, antara lain penggunaan kekerasan dan intimidasi; membius perempuan dan memaksa mereka untuk menelan kapsul yang berisikan narkoba lalu memaksa mereka untuk naik pesawat; dan menipu para perempuan tersebut sehingga mereka membawa narkoba tanpa sepengetahuan mereka sendiri, pada saat kembali dari apa yang mereka anggap sebagai liburan singkat di luar negeri.

Menurut penelitian yang dilakukan oleh Pusat Studi Wanita Universitas Tanjung Pura, untuk kasus Pengantin Pesanan setiap tahun kira-kira 50 perempuan ke Singkawang dari Taiwan dengan laporan mereka telah mengalami kekerasan dan penipuan, yaitu mulai dari dinikahkan dengan lelaki yang jauh lebih tua atau dengan lelaki yang cacat mental atau fisik yang parah yang tidak diungkapkan, sampai hidup sebagai pelayan tanpa bayaran, di 
paksa bekerja tanpa bayaran di pabrik atau industri rumah tangga, mengalami kekerasan fisik dan mental, atau di paksa bekerja dalam prostitusi ${ }^{1}$.

Konsorsium Pembela Buruh Migran Indonesia (KOPBUMI) memperkirakan pada tahun 2001, terdapat sekitar 1 juta buruh migran atau 20\% dari jumlah buruh migran Indonesia telah diperdagangkan. Sementara ILO/IPEC memperkirakan terdapat sekitar 8 juta anak Indonesia di bawah usia 15 tahun yang dieksploitasi untuk bekerja. Pengguna perdagangan manusia yang berkaitan dengan upaya eksploitasi pekerja antara lain mucikari dan pengelola rumah bordil, para pengusaha yang membutuhkan pekerja anak yang diberi upah murah, Agen Penyalur tenaga kerja yang tidak bertanggung jawab, keluarga menengah dan atas yang memerlukan perempuan dan anak untuk dipekerjakan, keluarga yang ingin mengadopsi anak, dan sebagainya.

Sedangkan data yang dihimpun oleh Markas Besar Kepolisian Negara Republik Indonesia (Mabes Polri) menunjukkan bahwa pada tahun 1999 terdapat 175 kasus dan selesai diproses 134 kasus; tahun 2000, 24 kasus selesai 16 kasus; tahun 2001178 kasus, selesai 128 kasus; tahun 2002, 155 kasus, selesai 90 kasus; tahun 2003, 21 kasus, 3 dalam tahap penyidikan dan 6 kasus dilanjutkan ke kejaksaan. Disamping itu sepanjang tahun 2003 RS Polri Kramat Jati Jakarta Timur, telah melayani 140 orang perempuan korban kekerasan, yang pulang dari wilayah Timur Tengah (Kompas, 1 Oktober 2003). Data tersebut menunjukkan bahwa apabila dibandingkan dengan data LSM, terdapat relatif banyak kasus perdagangan perempuan terjadi di Indonesia, namun penyelesaiannya oleh Kepolisian, masih jauh dari harapan.Kasus yang belum dapat diungkap relatif banyak dan tampaknya pihak Kepolisian mengalami berbagai kendala dalam upaya menindak para pelaku perdagangan perempuan dan anak.

Disamping hal tersebut, dari berbagai hasil penelitian yang dilakukan oleh berbagai Lembaga Swadaya Masyarakat ${ }^{2}$ terungkap antara lain bahwa dalam proses peradilan sejak dalam penyidikan, penuntutan dan peradilan terjadi berbagai tindakan yang dapat menghambat upaya pemberantasan perdagangan perempuan dan anak. Tindakan tersebut antara lain: polisi mengenakan biaya untuk menyelidiki tuduhan kriminal, memanipulasi berita acara pemeriksaan (BAP), jaksa dan hakim mengubah sifat kejahatan dari bersanksi relatif berat menjadi kejahatan dengan sanksi yang relatif ringan. Misalnya dalam kasus perdagangan perempuan untuk eksploitasi seksual dengan cara penipuan dan kekerasan,

\footnotetext{
${ }^{1}$ Andy Yetriyani, Politik Perdagangan Perempuan, Galang Press, Yogyakarta, B.Arsana, “Brides For Sale”, Latitudes, 2001, Hlm. 99.

${ }^{2}$ Ruth Rosenberg,Perdagangan Anak dan Perempuan di Indonesia,ICMC, 2003, Hlm. 170
} 
menjadi penipuan yang ancaman sanksinya relatif lebih rendah, selain itu disinyalir adanya penyuapan terhadap hakim.

Perdagangan perempuan dan anak tidak lagi terbatas pada batas wilayah negara melainkan berlangsung lintas batas, pola perdagangan pun berubah tidak lagi hanya dilakukan perseorangan melainkan sindikat terorganisir yang seringkali memiliki kegiatan illegal lainnya seperti penjualan obat adiktif dan senjata. Tujuan perdagangan juga tidak lagi sebatas untuk prostitusi atau menjadi pekerja di tempat hiburan, tetapi juga sebagai buruh migran dan mempelai pengantin perempuan.Dalam hal ini berbagai bentuk kekerasan harus dihadapi para korban, seperti kekerasan fisik, psikologi, sosial dan ekonomi. Kekerasan tersebut dilakukan baik oleh perekrut, pelanggan , suami/keluarga, maupun pemilik tempat kerja, juga oleh negara (aparat Pemerintahan termasuk Polisi) dan masyarakat di daerah asal dan tempat perdagangan tersebut.

Di Indonesia setidaknya ada 7 bentuk perdagangan perempuan baik didalam negeri maupun ke luar negeri, perempuan-perempuan tersebut di perdagangkan sebagai pekerja domestik, pengemis, pengedar napza (obat adiktif), pekerja non domestik dengan kondisi kerja yang sangat buruk, pekerja seks, pemuas pedofil, bahkan sebagai pengantin perempuan dalam perkawinan transnasional ${ }^{3}$.

Kegiatan perdagangan manusia pada umumnya terdiri dari rekrutmen, transportasi, transfer (alih tangan), penampungan, dan penerimaan.Modus operandi rekrutmen biasanya dengan rayuan, dengan menjanjikan berbagai kesenangan dan kemewahan, menipu atau janji palsu, menjebak, mengancam, menyalahgunakan wewenang, menjerat dengan hutang, mengawini, memacari, menculik, menyekap, dan memperkosa. Modus lain berkedok tenaga kerja untuk bisnis hiburan di luar negeri dengan bayaran besar. Memalsu identitas banyak dilakukan terutama untuk perdagangan manusia ke luar negeri. Unit Pemerintahan RT/RW, Kelurahan dan Kecamatan dapat terlibat pemalsuan KTP atau akte kelahiran, sebagai syarat memenuhi umur tertentu yang dituntut oleh agen untuk pengurusan dokumen (paspor).

Perempuan yang telah direkrut dibawa ke tempat transit atau ke tempat tujuan dalam rombongan dengan 1 sampai 20 orang temannya yang lain dengan menggunakan pesawat terbang atau mobil tergantung pada tujuannya.

Biasanya agen atau calo menyertai mereka dan menanggung biaya perjalanan.Untuk ke luar negeri, mereka dilengkapi dengan visa turis, tetapi seluruh dokumen dipegang oleh agen termasuk masalah keuangan.Seringkali perjalanan dibuat memutar untuk memberi

\footnotetext{
${ }^{3}$ Laporan pemetaan Komnas Perempuan Tahun 2001
} 
kesan bahwa perjalanan yang ditempuh sangat jauh sehingga sulit untuk kembali.Bila ada keinginan korban untuk kembali pulang, mereka sering ditakut-takuti atau diancam.

Sampai di tempat tujuan, para korban tinggal di rumah penampungan untuk beberapa minggu menunggu penempatan kerja yang dijanjikan. Kemudian mereka dibawa ke bar, pub, salon kecantikan, rumah bordil dan rumah hiburan lainnya, dan mulai dilibatkan dalam kegiatan prostitusi. Mereka diminta menandatangani kontrak yang tidak mereka pahami isinya.Jika mereka menolak, maka korban diminta membayar biaya perjalanan dan "tebusan" dari agen atau calo yang membawanya.Jumlah biaya itu menjadi hutang yang harus ditanggung oleh korban. Maka di sinilah mulai proses eksploitasi dengan ancaman dan pemerasa.

Pemerintah Indonesia sejak tahun 1984 sebenarnya telah meratifikasi Konvensi penghapusan segala bentuk kekerasan terhadap perempuan dan dalam deklarasi penghapusan segala bentuk kekerasan terhadap perempuan tahun 1992, sebagai penjabaran pasal konvensi tersebut, telah dimuat pembahasan tentang perdagangan perempuan dan anak untuk tujuan eksploitasi seksual/pelacuran. Ternyata dalam perkembangannya pemerintah Indonesia telah disorot oleh dunia sebagai Negara yang kurang tanggap terhadap persoalan tersebut.Terutama ketika pemerintah Amerika Serikat memasukkan Indonesia dalam kelompok Negara dengan peringkat terendah karena dianggap kurang melakukan upaya penanggulangan trafiking.Hal ini menggugah semua pihak dan mendorong pemerintah Indonesia untuk segera melakukan tindakan pencegahan dan penanggulangan terhadap kegiatan yang bertujuan untuk mengeksploitasi perempuan serta anak, serta menyatakan perang terhadap perdagangan manusia.Melalui Menteri Koordinator Kesejahteraan Rakyat pada Rapat Koordinasi Bidang Kesra tanggal 17 Oktober 2001, Indonesia menegaskan bahwa dalam waktu tiga tahun Indonesia sudah harus masuk ke peringkat yang lebih tinggi. Pada tahun 2003 keinginan tersebut tercapai dan Indonesia termasuk negara peringkat dua, berarti Indonesia telah mulai melakukan berbagai usaha memerangi dan menghapus perdagangan manusia khususnya perdagangan perempuan dan anak.

\section{PEMBAHASAN}

Proses dan Mekanisme Pelaporan Kejahatan Perdagan Perempuan dan Anak masih terdapat kesulitan karena faktor adanya dualisme hukum, antara KUHP dan Undang-undang Perlindungan Anak sehingga mengakibatkan ada kesulitan untuk menetapkan pasal apabila sebuah tindak pidana terjadi undang-undang yang ada masih mempunyai kelemahan yang 
harus segera direvisi. Melalui revisi diharapkan undang-undang bisa lebih terinci mengakomodasi penanganan kasus trafficking. Di samping itu vonis pengadilan dianggap tidak sesuai dengan tindakan yang telah dilakukan tersangka. Kadang-kadang vonis yang dijatuhkan tidak sesuai dengan tuntutan yang tercantum pada pasal yang dikenakan.

Tanggapan polisi pada saat penerimaan laporan mengenai kasus perdagangan perempuan dan anak dalam lingkungan pekerjaan organisasi menyediakan bagi anggotanya berbagai stimulti yang lebih daripada apa yang bisa diprosesnya, dalam hal menangani kasus traffiking, stimuli didapatkan melalui pengayunan KUHP dan KUHAP, Petunjuk Pelaksanaan (Juklak), perintah, memo, petunjuk, disposisi dan lainnya. Persepsi anggota Polri mempengaruhi penegakan hukum atau akan mempengaruhi keputusan yang akan diambil anggota Polri dalam menangani kasus trafficking. Dalam penelitian ini terlihat bahwa kurangnya stimuli terhadap pemahaman tentang Hak Asasi Manusia termasuk Hak Perempuan serta kesetaraan gender, membuat petugas kepolisian mempunyai pandangan yang bias dan melakukan tindakan yang keliru Misalnya dalam kasus perzinahan yang biasanya dilaporkan kalau salah satu pihak merasa dirugikan, polisi dengan ringan mengatakan bahwa biasanya didamaikan dan dinikahkan saja. Misal yang lain ialah masih banyak petugas yang masih menganggap perdagangan bayi merupakan masalah intern keluarga karena dilakukan oleh suami atau pacar si ibu, sehingga polisi tidak perlu ikut campur.

Penanganan Kasus Perdagangan Perempuan dan Anak Oleh Polisi diawali dengan pelaksanaan proses penyelidikan dan penyidikan. Proses ini dilakukan oleh polisi dengan berpegang pada aturan yang berlaku dalam Criminal Justice System. Dalam KUHAP proses penanganan kasus sudah dibagi dalam beberapa tingkatan yaitu Penyidikan, Penuntutan dan Pengadilan. Responden menjelaskan apabila suatu kasus telah memenuhi persyaratan formal \& materiil maka kasus tersebut dapat diproses karena juklak \& juknis yang berlaku di lingkungan Polri sudah ada pentahapan.

Tahap I: Penyelidikan: penyelidikan itu dibagi 2, penyelidikan reserse terbuka \& tertutup dan hasilnya dilaporkan sebagai hasil penyelidikan.

Tahap 2: Penindakan, penindakan itu mulai Pemanggilan, Penyitaan, Penggeledahan, Penahanan \& sebagainya.

Tahap 3: Pemeriksaan, terdiri pemeriksaan saksi, saksi ahli, tersangka,

Tahap 4: Pemberkasan, dalam pemberkasan intinya kalau perkara itu tidak memenuhi persyaratan formal dan materiilnya maka perkara itu dihentikan baik demi hukum atau tidak cukup bukti. Menurut juklak \& juknis yang ada, kalau memenuhi persyaratan formal dan 
materiil maka berkas dikirim ke kejaksaan, seandainya menurut Kejaksaan masih ada yang kurang maka dikembalikan lagi ke Polisi untuk dilakukan penyempurnaan. Responden dalam menangani kasus perempuan selalu berkoordinasi dengan pihak Kejaksaan. Para responden menyatakan bahwa apabila BAP, tersangka, dan barang bukti sudah diserahkan ke kejaksaan, maka semua menjadi kewenangan pihak kejaksaan dan Polisi tidak dapat lagi melakukan kontrol penanganan selanjutnya. Polisi hanya menunggu salinan vonis yang juga tidak pasti akan dikirim oleh kejaksaan atau tidak. Artinya apabila suatu kasus telah dilimpahkan ke kejaksaan, maka Penyidik tidak dapat lagi memantau sampai adanya putusan dari pengadilan.

Kendala yang dialami Penegak Hukum Dalam Menangani Tindak Pidana Perdagangan Perempuan dan Anak kendala yang dihadapi polisi dalam mengungkap berbagai kasus perdagangan perempuan dan anak. Seperti Hukum Adat yang terdapat didaerah tersebut menganggap kasus yang terjadi bukalah sebuah Crime tetapi merupakan adat dan kebiasaan. Selain itu banyak korban tidak melanjutkan laporannya karena mereka tidak menganggap dirinya adalah korban Human trafficking. Serta faktor kendala yang bahwa masyarakat menganggap hal ini adalah sebuah perjanjian biasa yang dibuat sesuai dengan pasal 1320 KUHPerdata namun mereka tidak menyadarinya bahwa didalamnya terdapat unsur penipuan yang berakibat terpenuhinya unsur Human trafficking.

\section{PENUTUP}

\section{A. Simpulan}

Mekanisme Pelaporan Kejahatan Perdagangan Perempuan dan Anak masih terdapat kesulitan karena faktor adanya dualisme hukum, antara KUHP dan Undang-undang Perlindungan Anak sehingga mengakibatkan ada kesulitan untuk menetapkan pasal sebagai sanksi yang tepat bagi pelaku. Sehingga kasus perdagangan perempuan dan anak makin marak dan sulit untuk penanganan oleh Polisi di wilayah Kalimantan dan Jawa. Karena pada saat Polisi hendak menangani kasus tersebut Polisi berbenturan dengan Hukum Adat dimana dari Adat dan Kebiasaan yang masyarakat anggap benar perbuatan tersebut bukanlah merupakan kejahatan melainkan sebuah hal yang biasa saja.

\section{B. Saran}

Penulis menyarankan kepada pemerintah sebaiknya membuat rumusan undangundang perdagangan manusia yang lebih terinci sehingga dapat lebih mengakomodasi 
penanganan kasus trafficking. Serta Pihak Kepolisian harus meningkatkan stimulti terhadap pemahaman tentang Hak Asasi Manusia termasuk Hak Perempuan serta kesetaraan gender, agar petugas kepolisian tidak bias dan melakukan tindakan yang keliru dalam menangani kasus Human Trafficking.

\section{IV.DAFTAR PUSTAKA}

\section{Buku}

Andy Yetriyani, Politik Perdagangan Perempuan, Galang Press, Yogyakarta, B.Arsana, "Brides For Sale", Latitudes, 2001.

Komisi Perlindungan Anak Indonesia, Hasil Pengawasan Perlindungan Anak Di Indonesia, Memahami Masalah Perdagangan Anak, KPAI, September 2015

Rika Saraswati, Hukum Perlindungan Anak Di Indonesia, Citra Aditya Bakti, Bandung, 2015

Rizky Ariestandi Irwansyah, Hukum, Hak Asasi Manusia, dan Demokrasi, Graha Ilmu, Yogyakarta, 2013

Ruth Rosenberg, Perdagangan Anak dan Perempuan di Indonesia,ICMC, 2003

Waluyadi, Hukum Perlindungan Anak, Mandar Maju, Bandung, 2009

\section{Perundang - Undangan}

Deklarasi Penghapusan Kekerasan terhadap Perempuan (Declaration on the Elimination of Violence against Women) Tahun 1993.

Depdagri. Pengarusutamaan Gender dalam Pembangunan Nasional. Inpres 9/2000, 2001. Pengarusutamaan Gender dalam Pembangunan Nasional.

International Covenant on Civil and Political Rights (ICCPR) 1966.

International Covenant on Economic, Social, and Cultural Rights (ICESCR) 1966.

Kementerian Negara Pemberdayaan Perempuan RI, 2006, Mengenal Teknik Analisis Gender dengan Metode PROBA (Problem Based Approach).

Kepmendagri 132 Tahun 2003.

Keppres No. 36 Tahun 1990 Mengenai Ratifikasi Konvensi PBB tentang Hak-Hak Anak Joint Decree 2002.

Universal Declaration of Human Rights (UDHR) 1948.

UU No. 7 Tahun 1984 tentang Ratifikasi CEDAW. 
Penanganan Polisi Terhadap Kasus Perdagangan Perempuan Dan Anak Di Kalimantan Dan Jawa - Anggreany Haryani Putri, Koesparmono Irsan

UU No. 21 Tahun 2007 tentang Pemberantasan Tindak Pidana Perdagangan Orang.

Kitab Undang-Undang Hukum Acara Pidana (KUHAP)

UU No. 39 Tahun 1999 tentang Hak Asasi Manusia (HAM)

UU No. 35 Tahun 2014 tentang Perlindungan Anak

\section{Jurnal / Makalah}

Bintari, A., \& Djustiana, N. Upaya Penanganan Korban dan Pencegahan Tindak Perdagangan Orang (Human Trafficking) di Kabupaten Indramayu Provinsi Jawa Barat. Jurnal Ilmu Pemerintahan. Vol. 1, No. 1, (2015). Hal. 124-148.

Bas, A. (2015). Getting Scrawed: Sex Workers and the Law. Lebanon: University Press of New England.

Cullen-DuPont, K. (2009). Human Trafficking. New York: Infobase Publishing.

Ebbe, O. N. I., \& Das D. K. (2008). Global Trafficking in Women and Children. USA: CRC Press, Taylor \& Prancis Group.

Fredette, K. International Legislative Efforts to Combat Child Sex Tourism: Evaluating the Council of Europe Convention on Commercial Child Sexual Exploitation. Boston College International and Comparative Law Review.Vol. 32, (2009). Hal. 1-43.

Jones, S. V. Ending Bacha Bazi: Boy Sex Slavery and the Responsibility to Protect Doktrin. Ind. Int'1 \& Comp. Law Review. 25 (2015). P. 63-78.

Kusmanto, T., Y. Trafficking: Sisi Buram Migrasi Internasional. Jurnal SAWWA. Vol. 5, No. 2, (2014). Hal. 219-240.

Lapian, M., G. \& Geru, A., H. (2010). Trafficking Perempuan dan Anak: Penanggulangan Komprehensif Studi Kasus: Sulawesi Utara. Jakarta: Yayasan Obor Indonesia.

Montgomery, H. Defining Child Trafficking \& Child Prostitution: the Case of Thailand. Seattle Journal for Social Justice. Vol. 9, (2011). Hal. 774-811. 